\title{
Cytogenetic study of the Spanish goat breed Murciana-Granadina
}

\author{
I Burguete \\ Facultad de Veterinaria, Universidad de Murcia, Laboratorio de Citogenética Animal, \\ Genética y Mejora Animal, 30100 Espinardo, Murcia, Spain \\ (Proceedings of the 9th European Colloquium on Cytogenetics of Domestic Animals; \\ Toulouse-Auzeville, 10-13 July 1990)
}

goat / chromosomes / Murciana-Granadina breed

\section{INTRODUCTION}

In order to provide a basis to know the level of chromosome aberrations in populations of the autochthonous Spanish goat breed Murciana-Granadina, we have, for the first time, cytogenetically analyzed these goats. The number of chromosomes and chromosomal abnormalities are recorded.

This goat breed is distributed especially in southeastern (Granada, Almería, Murcia and Alicante) Spain (Mason, 1981) and one of its main virtues is its dairy potential (Del Amo García, 1983) principally to produce cheese (Poto, 1990, personal communication).

\section{MATERIALS AND METHODS}

The cytogenetic analyses were made on 106 animals ( 24 females, 82 males) coming from 7 cattle associations located in Murcia. The females were taken at random and the males had been preselected for testing.

Peripheral blood was cultured for conventional studies as previously described (Burguete et al, 1987) with some modifications (RPMI-1640 medium, Flow Dutch modifications and fetal calf serum, Gibco myoclone plus).

\section{RESULTS AND DISCUSSION}

The normal karyotype of the goat has $2 n=60$ chromosomes, all acrocentric except the $\mathrm{Y}$ chromosome which is the smallest and the only metacentric one.

The incidence of chromosomal abnormalities and their distribution in the seven cattle associations are shown in table I. It is interesting to note that out of 106 animals examined, only 2 of them showed centric fusions, one female taken 
Table I. Level of chromosomal abnormalities in Murciana-Granadina goats and their distribution in 7 cattle associations.

\begin{tabular}{|c|c|c|c|c|c|c|}
\hline \multirow{3}{*}{$\begin{array}{c}\text { Cattle } \\
\text { association }\end{array}$} & \multirow{2}{*}{\multicolumn{2}{|c|}{$\begin{array}{l}\text { No animals } \\
\text { examined }\end{array}$}} & \multicolumn{4}{|c|}{ Chromosomal abnormalities } \\
\hline & & & \multicolumn{2}{|c|}{ centric fusion } & \multicolumn{2}{|c|}{ other } \\
\hline & $M$ & $F$ & no & $\%$ & no & $\%$ \\
\hline El Palmar & 1 & 9 & $1(\mathrm{~F})$ & 11.1 & - & - \\
\hline EMEGA & 33 & 14 & $1(\mathrm{M})$ & 3.0 & - & - \\
\hline Calasparra & 1 & 1 & - & - & - & - \\
\hline Bullas & 18 & - & - & - & $1(\mathrm{M})$ & 5.5 \\
\hline Yecla & 13 & - & - & - & - & - \\
\hline Campos del Río & 12 & - & - & - & - & - \\
\hline Sangonera & 4 & - & - & - & - & - \\
\hline Total & 82 & & 1 & 1.2 & 1 & 1.2 \\
\hline & & 24 & 1 & 4.2 & & \\
\hline
\end{tabular}

M: male; F: female

at random (4.2\%) and one male preselected for testing (1.2\%) (figs 1 and 2) and one showed a break (1.2\%). All carriers were phenotypically normal.

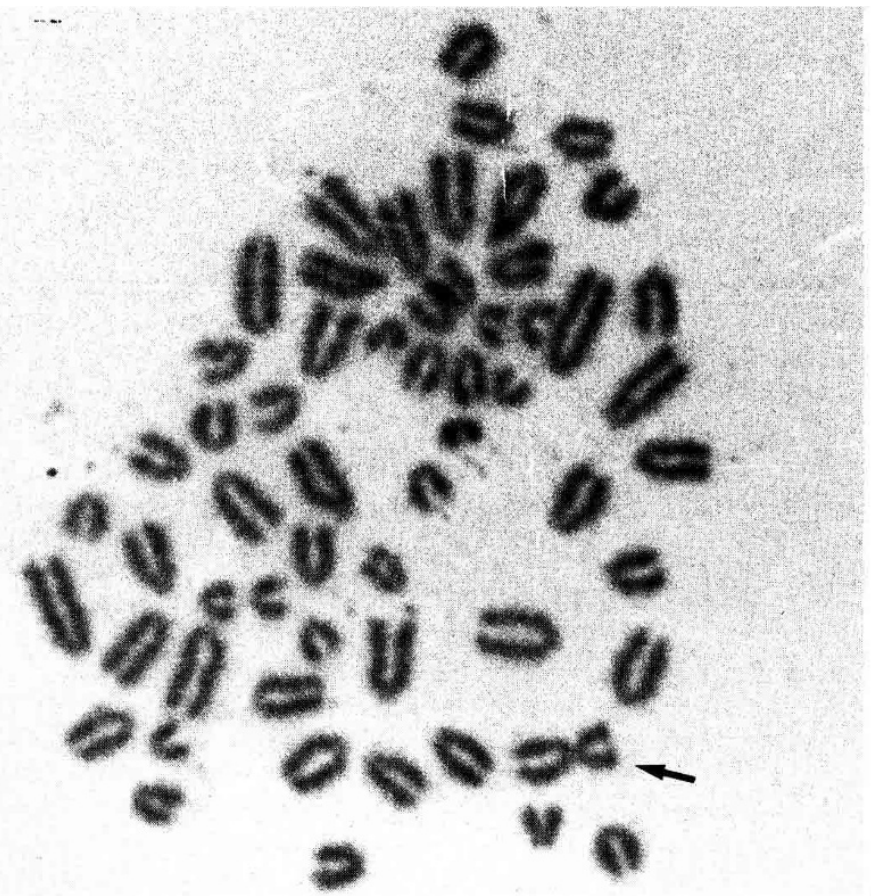

Fig 1. Metaphase plate of a female Murciana-Granadina goat carrying a centric fusion (arrow). 


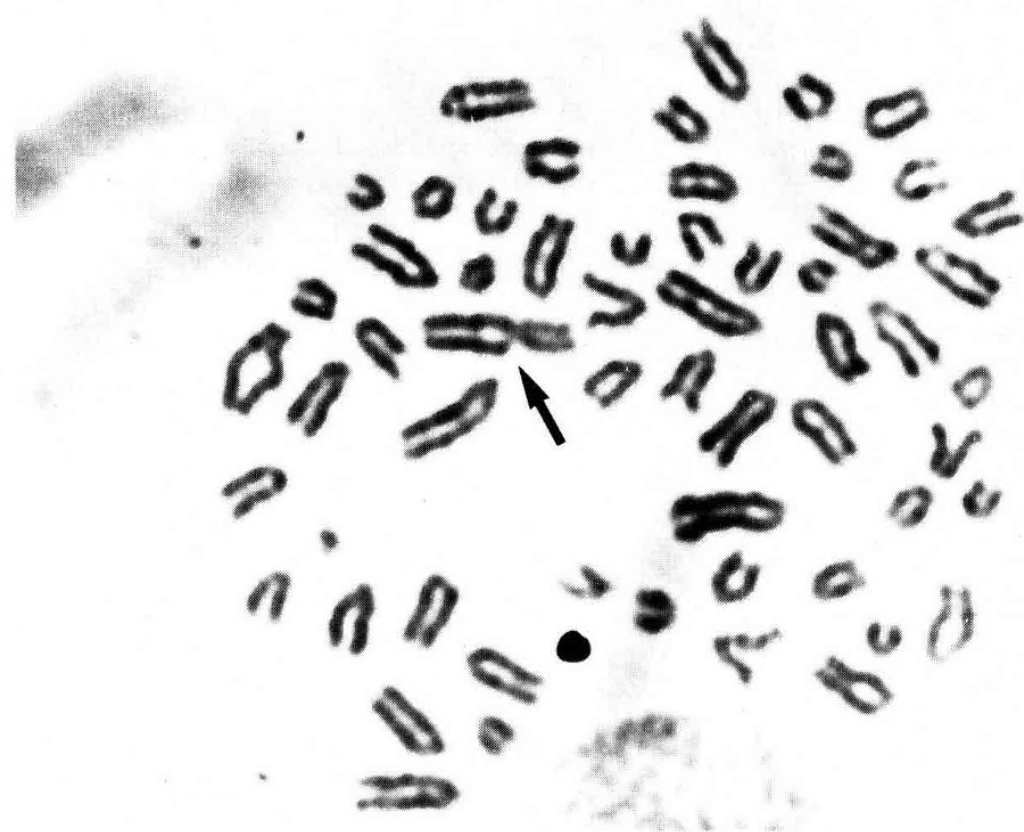

Fig 2. Metaphase plate of a male Murciana-Granadina goat carrying a centric fusion (arrow).

Caprine chromosomes have been studied using banding techniques such as the RBA technique (Di Berardino et al, 1987) for a definitive identification of the chromosomes involved.

It will be very interesting to further investigate these centric fusions in order to identify them and to see their possible effects on sperm production, prolificacy and other characters of interest.

\section{ACKNOWLEDGMENTS}

The author thanks Mr A Poto and his co-workers for excellent collaboration on this study; Mr M Zaragoza, Mr C Sánchez and Miss C Escoda for technical assistance. This work was supported in part by a grant from the Estación Regional de Mejora Ganadera, Consejería de Agricultura, Ganadería y Pesca de la Región de Murcia, España.

\section{REFERENCES}

Burguete I, Di Berardino D, Lioi MB, Taibi L, Matassino D (1987) Cytogenetic observations on a Robertsonian translocation in Saanen goats. Génét Sél Evol 19, 391-398

Del Amo Garcia (1983) Razas caprinas. In: Manual Sobre Cabras. Ministerio de Agricultura, Pesca y Alimentación, Madrid

Di Berardino D, Rønne M, Burguete I, Lioi MB, Taibi L, Matassino D (1987) The Rbanding pattern of the prometaphase chromosomes of the goat (Capra hircus L) J Hered $78,225-230$

Mason IL (1981) Breeds. In: Goat Production (Gall C, ed) Academic Press Inc, London 